\title{
Sharing the Risk? Households, Labor Market Vulnerability, and Social Policy Preferences in Western Europe
}

Silja Häusermann, University of Zurich
Thomas Kurer, University of Zurich
Hanna Schwander, University of Bremen

Explaining social policy preferences has become a major topic in comparative politics with labor market risk as a key determinant of these preferences. However, one question continues to loom large: are preference divides blurred by mixed households, that is, secure labor market participants living with vulnerable partners? In this article, we build on the insider-outsider literature and show that while the household does matter, its mitigating effect is limited in scope and strongly conditional on gender. Women's preferences depend on their partner's labor market situation, while men's preferences are unaffected by it. Overall, only a small minority of the population across Western Europe benefits from a "household safety net." Our findings have important implications for understanding the politicization of insideroutsider divides.

E xplaining social policy preferences has become a key topic in comparative politics. While for a long time, the study of welfare politics had been focused on power relations, institutions, and structural factors, recent contributions have forcefully argued that microlevel preferences matter for explaining both politics and policies (e.g., Cusack, Iversen, and Rehm 2006; Iversen and Soskice 2001; Manza and Brooks 2007; Rehm, Hacker, and Schlesinger 2012).

Over the last decades, advanced capitalist democracies have been experiencing fundamental structural changes in their labor markets. Deindustrialization, tertiarization, and labor market deregulation have profoundly altered the structure and distribution of labor market vulnerability, as the risks of unemployment and atypical employment have increasingly become concentrated among particular social groups (e.g., Bernardi and Garrido 2008; Eichhorst and Marx 2012; EspingAndersen 1999a; Oesch 2006; Ranci 2010).

It is thus not surprising that the impact of labor market transformation on social policy preferences of specific risk groups has become one of the most prominent questions in this field's literature. Scholars ask to what extent inequalities in the distribution of labor market risk shape political preferences and eventually political conflict by opposing different segments of the workforce (e.g., Dancygier and Walter 2015; Fernandez-Albertos and Manzano 2014; Gingrich and Ansell 2012; Häusermann 2010; Margalit 2013; Mughan 2009; Rehm 2009, 2011b; Walter 2010, 2015). Most specifically, this question has been taken up by the literature on dualization and insider-outsider divides, which examines how labor markets are divided between, on the one hand, workers in relatively secure, stable employment and, on the other hand, workers in unstable, flexible, or marginal employment (e.g., Emmenegger et al. 2012; Rueda 2005, 2007).

If mobilized and politicized, such a structural divide based on labor market vulnerability has the potential to cut across existing distributive conflict lines, hence its relevance for comparative politics. However, a necessary (though by far not sufficient) precondition for politicization is that people with dif-

Silja Häusermann (silja.haeusermann@ipz.uzh.ch) is professor of Swiss politics and comparative political economy at the Department for Political Science of the University Zurich, Switzerland. Thomas Kurer (kurer@ipz.uzh.ch) is a PhD student at the Department of Political Science of the University of Zurich, Switzerland. Hanna Schwander (hanna.schwander@uni-bremen.de) is a postdoctoral researcher at the SOCIUM - Research Center for Inequality and Social Policy at the University of Bremen, Germany.

Data and supporting materials necessary to reproduce the numerical results in the paper are available in the JOP Dataverse (https://dataverse.harvard.edu /dataverse/jop). An online appendix with supplementary material is available at http://dx.doi.org/10.1086/686972.

The Journal of Politics, volume 78, number 4. Published online August 18, 2016. http://dx.doi.org/10.1086/686972

(C) 2016 by the Southern Political Science Association. All rights reserved. 0022-3816/2016/7804-0007\$10.00 
ferent degrees of labor market vulnerability actually differ in their political preferences. Recent studies have established evidence for exactly such differences (e.g., Burgoon and Dekker 2010; Häusermann, Kurer, and Schwander 2015; Häusermann and Schwander 2011; Marx and Picot 2013; Rueda 2005). However, a key question has so far not been answered: as atypical employment and unemployment is unequally distributed between men and women, the divide between insiders and outsiders might run right through the middle of households (Pierson 2001, 448). Therefore, the household might mitigate or even obliterate preference divides between insiders and outsiders, thereby "neutralizing" the link between labor market vulnerability and preferences. In other words, living with a partner who enjoys stable employment and thus provides an economic safety net to the more vulnerable partner may erase the effect of labor market risk on preferences. Such a moderating effect of the household on insider-outsider divides has become a well-rehearsed claim in the welfare state literature for good reasons: an extensive literature in both sociology and household economics has long debated the extent to which and the conditions under which partners make choices and form preferences to the benefit of the household or their individual welfare (for a review, see Kan and Heath 2006; Pollak 2003). They find substantial effects of the household on preferences, especially for economically weaker women.

Despite these findings, the household question has hardly ever been addressed systematically in the political science literature. This is surprising, given the strong focus on microlevel preferences in the recent welfare state research and given the fact that - in line with the studies reported above - studies on voting behavior find strong household effects on electoral preferences, too (e.g., De Graaf and Heath 1992; Kan and Heath 2006; Strom 2014). Regarding the literature on dualization and insider-outsider divides, this relative neglect is particularly problematic since labor market vulnerability is so unequally spread between men and women. Taking the household into account may therefore have far-reaching implications. Indeed, knowing the extent to which individual labor market risk shapes social policy preferences is crucial for its consequences for a potential politicization of conflicts around insider-outsider divides: if most people's preferences for social and labor market policy are blurred or neutralized by their household situation, dualization is unlikely to ever become a politically salient conflict. Taking the household seriously is the goal of this article.

To date, we have very incomplete knowledge of the strength of this household effect, as well as on its scope across different countries. A working paper by Emmenegger (2010) and a conference paper by Barrows (2012) are to our knowledge the only empirical studies that integrated the household sit- uation of respondents explicitly in the empirical analysis. Both provide correlational evidence that people align their preferences to maximize overall household welfare. However, they fail to differentiate theoretically and empirically divergent effects for men and women, thereby implicitly assuming symmetrical dependencies between both partners' labor market vulnerability. Given the existing research in sociology (Kan and Heath 2006), economics (Neugart 2008), and the study of voting behavior (Iversen and Rosenbluth 2006, 2010; Strom 2014), it is crucial to distinguish effects according to gender. Moreover, these existing studies do not allow us to evaluate the relevance of the household in terms of its demobilizing effect on political conflict around labor market vulnerability. From a broader comparative politics perspective, however, the magnitude of this demobilizing effect is precisely what we need to know in order to evaluate the potential of insideroutsider divides to reshape welfare state politics.

Relying on survey data from the EU-SILC and the European Social Survey 4 from 2008, we show that individual labor market vulnerability impinges social policy preferences, even if we control for household composition: the more strongly individuals are affected by labor market vulnerability, the stronger are their preferences for redistribution and public job creation. Second, and most importantly, we show that household composition does matter, but its effect is very limited: the effect of the partners' labor market situation prevails over the individual risk situation only for a minority of respondents. Moreover, the household effect is clearly conditional on gender: women form their preferences with reference to their partners' labor market vulnerability, while this is generally not the case for men. Hence, our findings show that the household has the potential of neutralizing the effect of individual labor market vulnerability on preference formation for the specific social group of female outsiders living with a secure partner. This limited effect, however, remains far from rendering insider-outsider divides obsolete generally, as the share of female outsiders living with a secure partner remains between $2 \%$ and $13 \%$ of the population across European countries.

The implications for the potential politicization of insideroutsider divides in European welfare states are clear: such a politicization may not happen or even fail for many reasons, but if so, the household cannot be the only culprit. Rather, the gender-specific effects we find suggest a very specific mechanism: our results point to a multiplier effect of a spread of labor market vulnerability among male breadwinners, because men's labor market situation affects not only their own preferences but also the preferences of their spouses. Conversely, such a multiplying effect remains absent as long as vulnerability affects primarily dependent household members. Both 
the erosion of the male breadwinner model in Europe and increasing labor market vulnerability among men (OECD 2010, 18) should therefore rather increase the likelihood of a politicization of insider-outsider divides.

\section{THEORY}

The exceptional economic growth during the postwar decades allowed for male full employment, growing status homogenization and job security regulations, a relatively cohesive working class, and social peace. Since then, however, advanced industrial societies have moved to a postindustrial social and labor market structure. Ever fewer people's work biographies correspond to the industrial blueprint of stable, full-time, and fully insured insider employment, while a growing proportion of the population deviates from the standard model and incurs higher labor market risks. Together with institutional barriers to entry to European labor markets (Emmenegger 2009) and policy reforms to deregulate and flexiblize labor markets (Emmenegger et al. 2012), three structural changes drive the development toward an increasingly unequal distribution of labor market risks: the tertiarization of the employment structure, the educational revolution, and the feminization of the workforce. Since 2000, service sector employment outdid industrial employment throughout the OECD by a factor of two to three (Oesch 2006, 31). Jobs in the service sector differ from industrial employment, because they tend to be more polarized (Goos and Manning 2007; however, see also Oesch and Rodriguez Menes 2011) and they involve more atypical, nonstandard employment, especially for women (Kroos and Gottschall 2012). Part-time and temporary work has become widespread and accounts for most of the job creation in the EU since the 1990s. In addition to tertiarization, the educational revolution has led to a broader and more heterogeneous middle class. As a consequence, atypical employment and unemployment increasingly affect middle-class workers as well (Häusermann et al. 2015; Oesch 2006). Finally, the massive entry of women into paid work coincides with the spread of atypical employment throughout Western Europe (EspingAndersen 1999b; Estévez-Abe 2006). These structural trends have contributed to the unequal distribution of the risk of unemployment, involuntary temporary work, and part-time employment (Eichhorst and Marx 2012; Esping-Andersen 2000; Jessoula, Graziano, and Madama 2010; Palier and Thelen 2010). Such periods of unemployment and forms of involuntary atypical employment have clear negative implications for individuals in terms of lower income, reduced access to vocational training, and weak contribution records to social insurance schemes (Eichhorst and Marx 2012; Häusermann and Schwander 2012), but also with regard to the risk of being trapped in unstable and precarious employment and even poverty (Oesch 2006; Tomlinson and Walker 2012).

Both the scholarly literature and the public debate have addressed this increasingly unequal distribution of labor market vulnerability among the workforce in terms of dualization (Emmenegger et al. 2012; Palier and Rueda 2007; Thelen 2010), that is, growing inequality between insiders and outsiders with regard to labor market integration and social rights. European welfare states and labor markets are built on the premise of permanent and full-time employment. Hence, a deviation from this model of permanent, full-time employment may result in welfare losses and even poverty risks, in particular in social insurance based welfare states. For this reason, we consider all forms of employment that deviate from the standard employment relationship (i.e., atypical employment and unemployment) as conditions for employment risks and labor market vulnerability. Our understanding of outsiders thereby differs from a more narrow institutionalist distinction between outsiders and insiders based on employment protection only. By focusing on risk and vulnerability, we also deviate from a purely dichotomous conceptualization of insiders and outsiders on the basis of labor market status (full time vs. atypical or unemployed). Instead, we consider outsiders those who incur a particularly high risk for atypical employment and unemployment. In our view, such a definition on the basis of employment risk instead of employment status is better suited to grasp the political implications of labor market dualization. Individuals form political preferences not primarily on the basis of their momentary situation, but with regard to their expectations about current and future risks, which they derive from comparisons with the employment situation of people in their occupational reference group. ${ }^{1}$ A risk-based understanding of outsiders entails the additional advantage that it allows for a continuous measure of labor market vulnerability instead of a dichotomous measure which is empirically inadequate, since not all outsiders are equally exposed to labor market risks. ${ }^{2}$ In the following, we theorize the link be-

1. Many women, for example, work full time at a young age before (temporarily) withdrawing from the labor market for child rearing and possibly reentering the labor market for a part-time job. Their employment trajectories clearly deviate from a standard employment biography, a fact they are generally well aware of. On the formation of preferences with regard to current and prospective risks, see also Walter (2010; 2015), Rehm (2011a), Schwander and Häusermann (2013), and Margalit (2013).

2. Our conceptualization of labor market vulnerability resonates with the measure of unemployment risk that Rehm (2009, 2011a, 2011b) proposed. He provides evidence for the impact of unemployment risk on social policy demand. Our work differs from these contributions, as we take temporary employment and involuntary part-time employment into account when conceptualizing labor market risk. These are the forms of vulnerable employment that have spread most massively over the past two 
tween labor market vulnerability and social policy preferences first at the individual level, before contextualizing it with reference to the household in general and gender in particular.

Several recent studies have provided evidence for the claim that insiders and outsiders differ in their social policy preferences (Burgoon and Dekker 2010; Häusermann et al. 2015; Marx 2014; Marx and Picot 2013; Rueda 2005, 2007; Schwander and Häusermann 2013). ${ }^{3}$ For our study on household effects, we build on this literature, but we deviate from it in two respects: first, as explained above, we focus on the risk of being affected by unemployment or atypical employment rather than the labor market status. Second, we conceptualize social policy preferences with regard to the specific needs of labor market outsiders, rather than focusing on general preferences toward welfare state generosity or labor market regulation. Hence, we examine attitudes toward redistribution and public job creation. Based on a rational choice perspective of social policy preference formation, we suggest that labor market vulnerability affects social policy preferences, because social policies imply different distributive consequences for insiders and outsiders. The main difference between insiders and outsiders is the stability and extent of employment. Hence, insiders with stable and secure full-time employment should prefer social insurance policies, which distribute social rights and benefits in proportion to contributions. Conversely, individuals exposed to higher labor market vulnerability have a specific interest in redistributive policies, that is, social benefits distributed on the basis of need, which compensate for a weaker labor market integration (Reeskens and van Oorschot 2013). An alternative response to the specific needs of labor market outsiders is employment promotion, that is, a proactive strategy of creating jobs and fostering employability, rather than passively compensating individuals for income loss (Lister 2004; Morel, Palier, and Palme 2011; Palier 2006). Since unstable or limited access to the labor market is precisely what defines outsiders, such employment supporting policies - including child care policies, active labor market policies, and other policies facilitating labor market entry and enhancing employment opportunities - are in the interest of outsiders. Hence, our first hypothesis:

H1. The stronger an individual's labor market vulnerability, the stronger his or her support for income redistribution and public job creation.

decades and which are at the core of insider-outsider divides within the employed workforce.

3. Emmenegger (2009) contests such differences. However, he only investigates differences with regard to preferences for employment protection, which is arguably in the (current or prospective) interest of both insiders and outsiders.
Second, and most importantly, we argue that this link between labor market vulnerability and preferences needs to be contextualized with regard to household effects. Paul Pierson was among the first to voice doubts about the still widespread exclusive focus on individuals that characterizes much of the comparative political economy work on distributive preferences. He argued that labor market risks are distributed unequally across genders in many countries and thus run "right through the middle of households" (Pierson 2001, 448). Pierson's claim has since then loomed large in the literature. There are both intuitive and scientific reasons for the resonance of his claim. It is well known that labor market vulnerability is unequally distributed between men and women (e.g., Kroos and Gottschall 2012; Schwander and Häusermann 2013). Also, sociological research has shown time and again that gender differences in employment performance even amplify after marriage, with women becoming more vulnerable and men less so (e.g., Kan 2014). Hence, it seems intuitively plausible that many female outsiders live with male insiders, and this may affect their preferences. However, there is also a very substantial scientific foundation for the doubts Pierson voiced. Indeed, the question to what extent individuals sharing a household with a partner form their preferences based on the household's situation (rather than their individual characteristics) is an old and important debate in economics and sociology. In economics, Becker's work $(1964,1981)$ has introduced the idea of an altruist/interdependent family equilibrium, in which both partners pool their resources and align their preferences with what maximizes the household income. In terms of social policy, this implies that both partners go for policies that benefit the economically dominant-malepartner. This Becker equilibrium, however, presupposes that marriage is a stable, complete contract. If spouses keep current and future outside options in mind (Iversen and Rosenbluth 2006), they may behave more egoistically, as conceptualized by other economists in terms of a bargaining model of the family. A similar debate about the appropriate level of preference formation - the household or the individualhas taken place in sociology, distinguishing between the "borrowing" and the "independence" models of the family. In the former, the woman is supposed to borrow her class identity from her husband, whereas her choices are influenced by her own characteristics in the latter (Kan and Heath 2006; Sorensen 1994).

In political science, the effect of the household on microlevel preferences has been investigated only sparsely. A growing discussion can be found in the literature on voting and electoral choice providing evidence for the interdependence of political preferences of spouses. Much of the contributions in the voting literature, however, focus on mechanisms of 
interdependence such as communication, learning, and socialization (e.g., Johnston et al. 2005; Zuckerman, Fitzgerald, and Dasovic 2005), rather than on economic interdependencies, which are at the heart of our question and the debates in economics and sociology. Nevertheless, a few studies do provide evidence that the household affects political preferences, especially for economically dependent spouses (De Graaf and Heath 1992; Kan and Heath 2006; Strom 2014). In light of these studies, we argue that the dualization literature needs to take household dynamics more seriously, both theoretically and empirically. Iversen and Rosenbluth (2006) are an exception, as they show that - in line with the "bargaining" model of the household - the extent of the gender gap in preferences and behavior depends on the economic outside options women have in the labor market. The implication is again consistent with the doubt raised by Pierson: economic dependency makes people rely on the household. In the more narrow dualization literature, Emmenegger (2010) and Barrows (2012) are the only contributions that test whether living in a household makes a difference in terms of preferences of insiders and outsiders. However, they do not theorize or analyze the household effects thoroughly, but assume symmetrical dynamics for men and women and lack an estimation of the size of the demobilizing effect of household interdependencies on preferences.

We want to estimate the effect of the household on insideroutsider preference divides. Our core idea is that outsiders' precarious labor market situation can be secured or compensated by sharing a household with an insider. Hence, if partners pool their resources (as explicitly assumed by Becker [1981] and implicitly by Emmenegger [2010] and Barrows [2012]), the individual welfare of an outsider not only depends on her or his own labor market vulnerability, but on the entire household. Consequently, individuals take the maximization of household welfare into account in their preference formation. In the extreme, an alignment of preferences within the household may prevent labor market vulnerability from becoming a manifest conflict line in politics altogether (Barrows 2012). However, previous research shows that household effects are conditional on gender (e.g., Kan and Heath 2006; Pollak 2003; Strom 2014). Therefore, we want to establish to what extent and especially under what conditions the household situation affects the impact of an individual's labor market vulnerability on his or her distributive preferences. We do so by developing and testing two further hypotheses.

First, the mechanism how the household is supposed to affect preference formation relates to the provision of an economic safety net if the partner is in a secure labor market position. This idea corresponds to the resource-pooling model that Becker advocates. Hence, for respondents living with a partner who is shielded from labor market risks, the effect of her or his own labor market vulnerability is mitigated by the household situation. By contrast, for a respondent living with a partner who is herself or himself exposed to strong labor market risks, the household provides no safety net (i.e., contributes little to no resources to the pool) and therefore the respondent's own labor market situation is relevant for preference formation. In other words: people living with an insider may align their preferences with their economically stronger partner, whereas people living with an outsider are expected to advocate policies that respond to his or her own economic situation. Consequently, we expect a positive interaction effect between a respondent's and his or her partner's labor market vulnerability on social policy preferences:

H2. The partner's labor market vulnerability reinforces the link between the respondent's labor market vulnerability and his or her social policy preferences.

We take this argument a step further on the basis of the existing literature on women's preference formation. We suggest that the importance of the household effect, that is, the extent to which the partner's situation matters for an individual's preference formation is not uniform for men and women. Rather, we contend that this effect depends on the gender of the individual. Why do we expect men and women to react differently to their partner's labor market situation?

In the classical Becker efficiency model of a family with perfect labor division (Becker 1964, 1981), economic resources are pooled and the household is the basis of the welfare of all members. The most efficient equilibrium in Becker's conceptualization occurs when spouses specialize in different tasks, with male breadwinners specializing in outside work and women specializing in household work. Thereby, Becker argues, both spouses maximize their welfare and they both equally align their preferences with the household. This model implies a strong imbalance between partners in their economic strength, which explains why the economically weaker partner would align with the economically stronger partner in the interest of the entire household. In more recent times, however, with generally high divorce rates and higher rates of female labor market participation, household welfare maximization is not necessarily the dominant strategy for all household members (Iversen and Rosenbluth 2006, 2010). In particular, the extent to which spouses align their preferences to the household depends on their employment and income opportunities outside of the household. The weaker the outside options, the stronger the reliance on household welfare provision. This reasoning implies that people may behave according to the interdepen- 
dence model or the bargaining model, depending on their outsider options, that is, their individual economic power. Non-employment or weak labor market integration are considered the main reason for weak outside options.

However, these weakening factors universally affect women to a greater extent than men, not least because of additional, care-related negative effects on employment performance (Iversen and Rosenbluth 2006). These gender-specific limitations to employment performance and economic outside options are not only due to biological reasons, but they are deeply encrusted in social norms and even institutionalized in countless policy incentives for an unequal division of labor both in the welfare state and the labor market (Esping-Andersen 1999b; Orloff 1996). Therefore, women must expect weaker outside options than men and thus have a stronger incentive than men to take the labor market situation of their spouses into account in their preference formation. ${ }^{4}$ Neugart's (2008) study in labor market economics provides tentative support for this hypothesis: he shows that women who are only marginally employed or non-employed tend to support employment protection for the male breadwinner. Hence, the partner's labor market risk is expected to affect female preference formation more strongly and directly than male preference formation.

H3. Household effects are gender asymmetrical: women's preferences depend more strongly on the partner's employment risk than men's.

With this contextualization of the household effect by gender, we go beyond the simple question whether the household will prevent labor market vulnerability from becoming a politically relevant conflict line. Rather, it will allow us to understand the conditions under which this could be the case, that is, the conditions under which dualization may actually transform postindustrial welfare politics.

\section{DATA, OPERATIONALIZATION, AND METHODS}

Our empirical work is based on data from the European Social Survey (ESS) round 4 (2008), which includes 13 West European countries. ${ }^{5}$ Apart from the high quality of ESS data, this survey is to date the only comparative data source that

4. The same mechanism explains why women should generally be more favorable than men toward welfare policies that provide a publicly funded outside option, as well as toward specific social policies that support women's labor market participation (Estévez-Abe 2006; Estévez-Abe, Iversen, and Soskice 2001). This is precisely the reason why we will control for gender in our analyses.

5. Belgium, Switzerland, Germany, Denmark, Spain, Finland, France, Greece, the Netherlands, Norway, Portugal, Sweden, and the United Kingdom. contains both detailed information on labor market situation and occupation, as well as particularly detailed questions on attitudes toward different social policies, as the 2008 wave includes a specific module of questions on welfare attitudes. In the following, we give a brief description of the main dependent and independent variables. ${ }^{6}$

We measure preferences for need-based redistribution by means of a question asking whether respondents think that the government should take measures to reduce income differences. ${ }^{7}$ For preferences regarding policies of publicly supported employment creation, we use a question asking whether respondents think that it is the government's responsibility to provide a job for everyone who wants one. This variable clearly focuses on employment rather than compensation of income loss. Both variables are recoded, so that higher values reflect higher preferences for the specific social policy.

The degree of labor market vulnerability is our main independent variable. We conceptualize vulnerability as the risk of being unemployed or/and in atypical employment (involuntary part-time, temporary employment, or helping in a family business). For each individual, we measure this risk on the basis of the frequency of unemployment and atypical employment within his or her occupational group, as the risk of an individual depends strongly on the incidence of atypical employment and unemployment in that person's occupational group (for an extensive discussion of our operationalization of labor market vulnerability, its validity, and implications, see Schwander and Häusermann 2013). Similarly to Rehm's work on unemployment risk (Rehm 2009, 2011a, 2011b), we rely on occupational groups for the measurement of group-specific frequencies of unemployment or atypical employment, because these frequencies vary considerably across occupational groups. In computing group-based frequencies as a measure of risk, it is crucial to choose theoretically relevant and meaningful reference groups. The goal should be to use reference groups that are reasonably homogeneous in the labor market conditions their members are exposed to, both in the present as in the future. At the same time, the reference groups should be defined by salient social characteristics, because we would like to choose groups in a way that the individuals can be reasonably expected to compare themselves to this group and

6. Detailed information on all operationalizations can be found in table A1 in the appendix.

7. The variable corresponds to a standard measure of redistribution preferences; see Jaeger (2006, 2009), Kulin and Svallfors (2013), Rehm (2011a), Hacker, Rehm, and Schlesinger (2013). It has the advantage that it refers directly to politics, that is, government action, rather than asking about a general attitude on income differentials, a variable that is also available. We ran all tests with both variables and results are robust. 
derive information about their own risk from the occurrence of a grievance in this very reference group.

Therefore, we construct our occupational reference groups on the basis of the most important sociostructural determinants of unemployment and atypical employment. The three sociostructural determinants we take into account are class, gender, and age, which are all strong predictors of labor market chances (Chauvel 2009; Esping-Andersen 1999a; Oesch 2006, 2013; Schwander and Häusermann 2013; Taylor-Gooby 1991). In other words, we assume that individuals can be reasonably expected to derive information on their labor market risk from what happens to their colleagues of the same gender, the same age group, and in similar occupations. Class, gender, or age alone would provide much too heterogeneous groups to provide relevant information to its members.

With regard to class, we use the class schema by Oesch in the collapsed version of Kitschelt and Rehm (Kitschelt and Rehm 2006; Oesch 2006). They distinguish five occupational classes: (i) high-skilled managers, self-employed, and technical experts (which they call capital accumulators); (ii) high-skilled professionals in the public and private service sector (sociocultural professionals); (iii) unskilled and skilled workers mostly in industry (blue-collar workers); (iv) unskilled and skilled employees in interpersonal services (low service functionaries); and (v) routine and skilled clerks (mixed service functionaries). ${ }^{8}$ We further distinguish those five classes according to gender and age.

The combination of five classes, two sexes, and two age groups (below/above or equal to 40 ) leaves us with 20 occupational groups, which serve as the basis of our measurement. ${ }^{9}$ We compute the rates of unemployment, involuntary part-time, or temporary employment ${ }^{10}$ for each occupational group and the average workforce in every country with data of the EU-SILC from 2007. We then subtract the average rate of the workforce from the group-specific rates in each country, in order to obtain the group-specific deviations (over- or underrepresentation) in unemployment, involuntary parttime, and temporary employment. ${ }^{11}$

8. Relying on this class scheme implies that we include all respondents in our analysis who have been attributed an isco-code in the ESS data. The isco-code is based on the current or last occupation, so that we also include most unemployed, housewives and pensioners in the data. Generally, less than $8 \%$ of all respondents lack information regarding the isco-code.

9. We set 40 as the age threshold because a substantial share of the population is still in education in their thirties in most European countries (Couppi and Mansuy 2003).

10. Due to their low proportion ( $1.2 \%$ of respondents), we refrained from constructing a separate category for helping in a family business and added them to the category of temporary employment.

11. The reason for subtracting the national average from the groupspecific values lies in the relational nature of labor market risks. A group-
The average of these three standardized deviations provides us with a continuous measure of labor market vulnerability, which is specific to an occupational group in a country. ${ }^{12}$ We then attribute the value to each respondent in our main data set, the ESS $2008 .{ }^{13}$ Respondents belonging to occupational groups with a lower labor market vulnerability than the entire workforce have negative values on our indicator of vulnerability, while respondents belonging to groups with a labor market vulnerability that exceeds the national workforce average have positive values. The availability of information on the occupational profile of the partner in the ESS allows us to compute the very same measure of labor market vulnerability for the respondent's partner.

The distribution of labor market vulnerability is, as expected, highly unequal between the occupational groups but also between gender, generations, and economic sectors. Labor market vulnerability is most unequally distributed in the countries of Continental and Southern Europe and also higher on average than in the Nordic countries or in Great Britain (see fig. B1 in the appendix; apps. A-E available online). In the appendix we also provide an extensive discussion of the vulnerability scores of different occupational groups across the countries. Table B1 shows that women, workers below the age of 40 , and low-skilled individuals are the most vulnerable groups across all countries. More specifically, female low-skilled service sector workers and female blue-collar workers (a comparatively small group) are the most vulnerable groups, while male medium- and highskilled managers and technical experts enjoy the most secure positions. Jobs in the service sector are characterized by a higher labor market vulnerability, confirming the insights from labor market sociology about the higher rates of vulnerability and nonstandard contracts in service sector jobs,

specific unemployment rate of $10 \%$ has a different meaning in a country with a national unemployment rate of $5 \%$ than in a country where unemployment is at $15 \%$

12. As a robustness check, we computed labor market vulnerability also in two additional ways, one including only the deviation from the national average on unemployment and one relative to atypical employment only (involuntary part-time and temporary employment). Our results are robust to the three specifications of labor market vulnerability, with household effects being weaker for the measure based on unemployment only.

13. We do not calculate the values of labor market vulnerability directly in the ESS for one main reason: the number of cases. The number of respondents (3,500-8,500 respondents for each country) in the EU-SILC is unrivaled by any comparative survey. It thus allows a precise measurement of labor market vulnerability across countries even for those groups which are naturally small (such as older female blue-collar workers, for example) which is even more important since we rely on labor market conditions (unemployment, atypical employment) that affect small portions of the workforce only. 
particularly at the lower end of the skill distribution (see Oesch 2006, 2013). It is precisely these less secure, nonstandard, low-skilled service jobs that continue to foster employment growth, together with the more stable and highly paying service jobs at the top of the skill distribution (Oesch and Rodriguez-Menes 2011; Wren 2013). The high degree of vulnerability in the lower skilled jobs in the manufacturing sector (blue-collar workers), by contrast, results largely from deindustrialization. Therefore, labor market risk in these sectors consists mainly of unemployment risks, as jobs are shrinking (see Schwander and Häusermann [2013] for a more detailed decomposition of unemployment and atypical employment risks). The recent economic crisis in Europe has exacerbated these unemployment risks.

Given the construction of the occupational reference groups based on the major determinants of unemployment and atypical employment, our indicator of labor market vulnerability is obviously closely related to class, gender, and age. Therefore, including all these components in the model would by definition create severe problems of multicollinearity. At first glance, one may thus ask if our indicator of labor market vulnerability actually adds value to the information on a respondent's occupational reference group. It indeed does, because it represents the actual mechanism through which we expect membership in these groups to affect social policy preferences. Consequently, we need to control in our analyses for rival mechanisms that might relate these same groups to policy preferences. Therefore, we include a range of control variables that have been shown to be relevant in previous research (De La O and Rodden 2008; Emmenegger 2009; Rehm 2009, 2011a, 2011b; Rueda 2005; Scheve and Stasavage 2006). We include household income (measured in deciles), public employment, and trade union membership as well as gender, age, educational levels (the highest achieved educational degree), the number of children, and migrant status. To control for the influence of cultural values which have also been shown to be class related on social policy preferences, we include church attendance (how often do you attend religious services) and cultural liberalism (support for equal gay rights). ${ }^{14}$ To show that labor market risk matters more than the actual labor market sta-

14. We control for cultural liberalism to rule out the possibility that social policy preferences are an expression of a postmaterialist value orientation of specific occupational groups. The ESS does not allow measuring postmaterialist values as suggested by Inglehard (1977). However, we tried different additional operationalizations: support for law and order (people who break the law should be sentenced to harsher sentences), gender equality (women should be prepared to cut down on paid work for the sake of family), and a composite measure of the three indicators. The results are robust to all measures. tus, we include the type of contract (permanent vs. nonpermanent) in the analyses.

As the method of analysis, we use ordered logit regressions, as the number of West European countries in the ESS (13) is too small in order to properly test hypotheses in a multilevel framework (Stegmueller 2013). Instead, we employ country fixed effects to control for the fact that individuals are nested in countries and thus share the same macro context and country-clustered standard errors to correct for the within-country correlation of errors.

\section{EMPIRICAL RESULTS The effect of labor market vulnerability on individual social policy preferences}

Table 1 shows the determinants of preferences for redistribution and public job creation. For both dependent variables, we specify three models. The model 1 tests the direct effect of the respondent's labor market vulnerability. Model 2 introduces the partner's labor market vulnerability, to test whether the direct effect remains or disappears if we control for the household situation. Both model 1 and model 2 test our first hypothesis regarding the effect of the respondent's labor market vulnerability on social policy preferences. Model 3 introduces the household interaction effect that we postulated in hypothesis 2: we expect the respondent's labor market vulnerability to have a weaker effect on preferences when he or she lives with an insider than when he or she lives with a partner who is himself or herself exposed to labor market vulnerability.

We first discuss the linear effects in models 1 and 2 . They show that individual labor market vulnerability is clearly linked to higher support for redistribution and job creation. This is exactly what our hypothesis predicted, as it shows that labor market vulnerability shapes the social policy demand of individuals in ways consistent with the insideroutsider literature. Moreover, the effects remain consistent and robust when we control for the partner's labor market vulnerability, which is itself also positively correlated with demand for social policy. ${ }^{15}$ The control variables largely confirm the findings of previous studies on social policy preferences. We see that in addition to labor market risk, vertical stratification in terms of education and income structures welfare preferences strongly: both income and education have

15. It is important to note that for reasons of comparability, we include in our regressions only those respondents who actually do have a partner, which reduces our number of cases from about 19,000 to about 8,000 . When testing model 1 with all respondents included, our results remain robust. The core finding of model 1 also holds when looking only at those individuals without a partner (results shown in table $\mathrm{C} 1$ in the appendix). 
Table 1. Determinants of Social Policy Preferences: Coefficients from Ordered Logit Regressions

\begin{tabular}{|c|c|c|c|c|c|c|}
\hline & \multicolumn{2}{|c|}{ M1: Preference For... } & \multicolumn{2}{|c|}{ M2: Preference For... } & \multicolumn{2}{|c|}{ M3: Preference For... } \\
\hline & Redistribution & Job Creation & Redistribution & Job Creation & Redistribution & Job Creation \\
\hline Respondent's outsiderness & $\begin{array}{l}.187^{* * *} \\
(.06)\end{array}$ & $\begin{array}{l}.178^{\star *} \\
(.07)\end{array}$ & $\begin{array}{l}.175^{* * *} \\
(.07)\end{array}$ & $\begin{array}{l}.171^{\star *} \\
(.07)\end{array}$ & $\begin{array}{l}.199^{* * *} \\
(.07)\end{array}$ & $\begin{array}{l}.188^{* * *} \\
(.07)\end{array}$ \\
\hline Partner's outsiderness & & & $\begin{array}{l}.160^{\star * *} \\
(.05)\end{array}$ & $\begin{array}{l}.092^{\star *} \\
(.04)\end{array}$ & $\begin{array}{l}.166^{\star \star \star *} \\
(.04)\end{array}$ & $\begin{array}{l}.094^{\star} \\
(.05)\end{array}$ \\
\hline Outsiderness respondent $x$ & & & & & & \\
\hline Outsiderness partner & & & & & $\begin{array}{l}.192^{* * *} \\
(.03)\end{array}$ & $\begin{array}{l}.152^{* *} \\
(.06)\end{array}$ \\
\hline Education & $\begin{array}{c}-.110^{* * *} \\
(.03)\end{array}$ & $\begin{array}{c}-.086^{* *} \\
(.04)\end{array}$ & $\begin{array}{l}-.104^{* * *} \\
(.03)\end{array}$ & $\begin{array}{c}-.083^{* *} \\
(.04)\end{array}$ & $\begin{array}{l}-.107^{* * *} \\
(.03)\end{array}$ & $\begin{array}{c}-.085^{\star *} \\
(.04)\end{array}$ \\
\hline Income & $\begin{array}{c}-.163^{* * *} \\
(.01)\end{array}$ & $\begin{array}{l}-.105^{\star * *} \\
(.02)\end{array}$ & $\begin{array}{l}-.155^{\star * *} \\
(.01)\end{array}$ & $\begin{array}{l}-.100^{* * *} \\
(.02)\end{array}$ & $\begin{array}{c}-.153^{\star * *} \\
(.01)\end{array}$ & $\begin{array}{l}-.099^{* * *} \\
(.02)\end{array}$ \\
\hline Female & $\begin{array}{r}-.047 \\
(.07)\end{array}$ & $\begin{array}{l}.109 \\
(.10)\end{array}$ & $\begin{array}{l}.102^{\star} \\
(.06)\end{array}$ & $\begin{array}{l}.195^{\star *} \\
(.08)\end{array}$ & $\begin{array}{l}.090 \\
(.06)\end{array}$ & $\begin{array}{l}.186^{* *} \\
(.08)\end{array}$ \\
\hline Age & $\begin{array}{l}.006 \\
(.00)\end{array}$ & $\begin{array}{r}-.001 \\
(.00)\end{array}$ & $\begin{array}{l}.007 \\
(.00)\end{array}$ & $\begin{array}{c}-.000 \\
(.00)\end{array}$ & $\begin{array}{l}.007 \\
(.00)\end{array}$ & $\begin{array}{c}-.000 \\
(.00)\end{array}$ \\
\hline Public employment & $\begin{array}{l}.135^{\star *} \\
(.06)\end{array}$ & $\begin{array}{l}.063^{*} \\
(.03)\end{array}$ & $\begin{array}{l}.143^{* *} \\
(.06)\end{array}$ & $\begin{array}{l}.067^{\star *} \\
(.03)\end{array}$ & $\begin{array}{l}.134^{* *} \\
(.06)\end{array}$ & $\begin{array}{l}.060^{*} \\
(.04)\end{array}$ \\
\hline Cultural liberalism & $\begin{array}{l}.216^{* * *} \\
(.04)\end{array}$ & $\begin{array}{l}.001 \\
(.07)\end{array}$ & $\begin{array}{l}.219^{* * *} \\
(.04)\end{array}$ & $\begin{array}{c}.003 \\
(.07)\end{array}$ & $\begin{array}{l}.221^{\star * *} \\
(.04)\end{array}$ & $\begin{array}{l}.003 \\
(.07)\end{array}$ \\
\hline Union membership & $\begin{array}{l}.317^{\star * *} \\
(.08)\end{array}$ & $\begin{array}{l}.353^{\star * *} \\
(.05)\end{array}$ & $\begin{array}{l}.304^{\star \star \star} \\
(.07)\end{array}$ & $\begin{array}{l}.346^{\star * *} \\
(.05)\end{array}$ & $\begin{array}{l}.300^{\star \star *} \\
(.08)\end{array}$ & $\begin{array}{l}.341^{\star * *} \\
(.05)\end{array}$ \\
\hline Children & $\begin{array}{l}.081^{\star * *} \\
(.02)\end{array}$ & $\begin{array}{l}.011 \\
(.05)\end{array}$ & $\begin{array}{l}.086^{\star * *} \\
(.02)\end{array}$ & $\begin{array}{c}.012 \\
(.05)\end{array}$ & $\begin{array}{l}.091^{\star * *} \\
(.02)\end{array}$ & $\begin{array}{c}.017 \\
(.05)\end{array}$ \\
\hline Immigrant status & $\begin{array}{c}-.152 \\
(.11)\end{array}$ & $\begin{array}{l}.069 \\
(.12)\end{array}$ & $\begin{array}{c}-.144 \\
(.11)\end{array}$ & $\begin{array}{l}.071 \\
(.12)\end{array}$ & $\begin{array}{r}-.147 \\
(.11)\end{array}$ & $\begin{array}{l}.071 \\
(.12)\end{array}$ \\
\hline Employment contract & $\begin{array}{c}-.063 \\
(.07)\end{array}$ & $\begin{array}{l}.038 \\
(.04)\end{array}$ & $\begin{array}{c}-.053 \\
(.07)\end{array}$ & $\begin{array}{l}.042 \\
(.04)\end{array}$ & $\begin{array}{r}-.045 \\
(.07)\end{array}$ & $\begin{array}{l}.045 \\
(.04)\end{array}$ \\
\hline Church attendance & $\begin{array}{c}-.049 \\
(.04)\end{array}$ & $\begin{array}{c}-.071^{\star *} \\
(.04)\end{array}$ & $\begin{array}{c}-.048 \\
(.04)\end{array}$ & $\begin{array}{c}-.070^{*} \\
(.04)\end{array}$ & $\begin{array}{c}-.043 \\
(.04)\end{array}$ & $\begin{array}{c}-.069^{*} \\
(.04)\end{array}$ \\
\hline Country fixed effects & Yes & Yes & Yes & Yes & Yes & Yes \\
\hline Pseudo $R^{2}$ & .172 & .113 & .174 & .114 & .175 & .115 \\
\hline $\mathrm{BIC}$ & $-41,347.6$ & $-27,468.9$ & $-41,351.1$ & $-27,464.3$ & $-41,353.7$ & $-27,463.0$ \\
\hline$N$ & 6,932 & 6,932 & 6,932 & 6,932 & 6,932 & 6,932 \\
\hline Log likelihood & $-9,855.4$ & $-16,768.2$ & $-9,849.2$ & $-16,766.0$ & $-9,843.5$ & $-16,762.3$ \\
\hline
\end{tabular}

Note. Data source: ESS 4 2008. Ordered logistic regression with clustered standard errors and country dummies, the data are weighted; Country dummies and cut-points are not shown due to space restriction; Pseudo $R^{2}$ is the McKley and Zavoina $R^{2}$

* Significant at the .10 level.

** Significant at the .05 level.

$* * *$ Significant at the .01 level.

the expected negative effect on social policy preferences. Gender, age, and immigration status have no consistent direct effect on preferences for redistribution and job creation. Also, having a nonpermanent contract does not have an effect on preferences for redistribution and public job creation. Cultural liberalism, public sector employment, union membership, and having children are positively related to at- titudes toward outsider-friendly policies while church attendance has a weak but consistently negative effect on these preferences.

It has been argued that insider-outsider preference divides are, even if significant, very small or even marginal (Emmenegger 2009; Pierson 2001). Figure 1 shows otherwise: it presents the substantive effects of labor market vulnerability 
Redistribution

"Government should take measures to reduce differences in income levels, 1 "disagree strongly" - 5 "agree strongly"

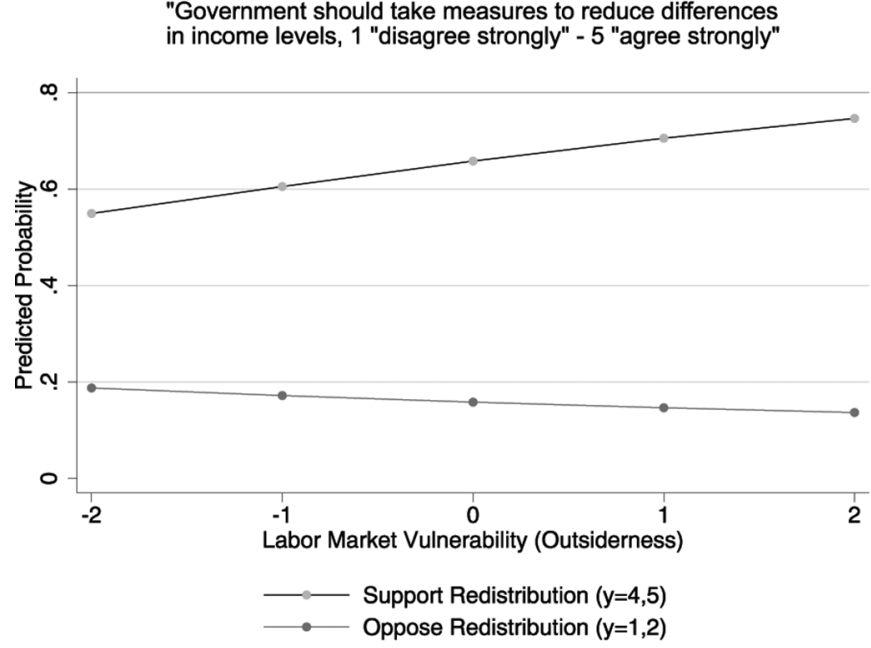

Jobcreation

"It is the government's responsibility to ensure a job for everyone who wants one? 0 "not responsible at all" - 10 "entirely responsible"

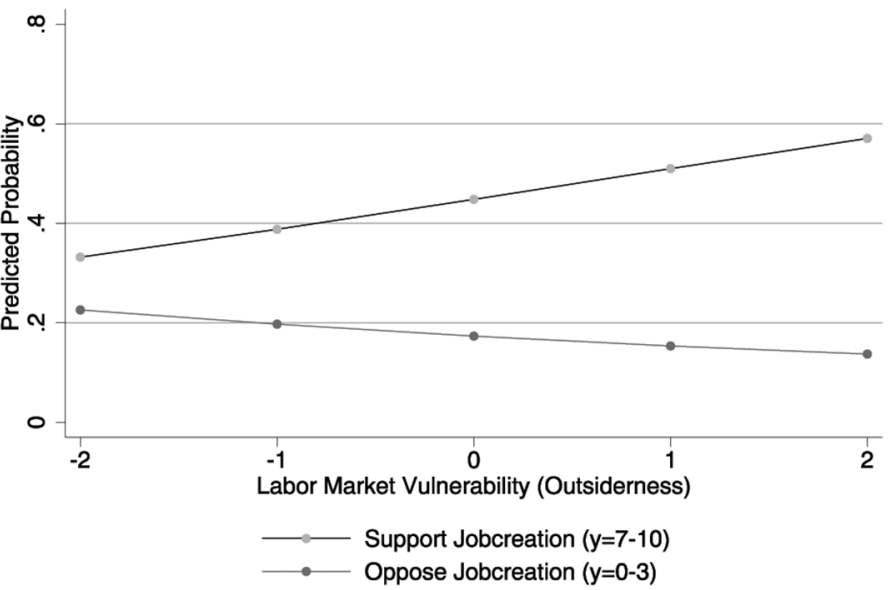

Figure 1. Predicted probabilities of supporting or opposing redistribution or job creation, depending on the respondent's outsiderness. All graphs based on model specifications of model 3 in table 1 (above, dependent variable dichotomized as indicated). Predicted probabilities for a respondent with median (/mean/mode) values on all categorical (/continuous/dummy) variables except outsiderness.

in terms of predicted probabilities to support or oppose redistribution or public job creation. For these calculations, we have recoded the two variables redistribution and job creation in terms of support or opposition as shown below each graph. Both graphs nicely show the considerable effect of labor market vulnerability. Going from the minimum level of vulnerability to the maximum, the probability that an average individual will support outsider-friendly policies increases by about 25 percentage points with regard to redistribution and even by nearly 30 percentage points regarding public job creation. ${ }^{16}$ Moreover, with rising labor market vulnerability, respondents become extremely unlikely to oppose redistribution, whereas pronounced insiders show probabilities of disapproval that range around 20\%. These results correspond to our expectation that labor market vulnerability substantially increases the support for a welfare state based on employment creation and need.

Does the fact that labor risks run through the middle of the household affect the effect of labor market vulnerability on social policy preferences? Model 3 in table 1, as well as figure 2 presents the results for the interaction effect. We find the positive interaction effects we expected in hypothesis 2: the partner's labor market vulnerability reinforces

16. The average individual is a 48-year-old woman with an upper secondary degree, who is not a union member, has a household income within the sixth earning decile, agrees that gays and lesbians should live as they wish, is not a public servant, does not have children living at home, is a citizen of the country, has an unlimited working contract, and attends church only on special holidays. the effect of the respondents situation on his or her support for outsider policies.

Figure 2 shows that the marginal effect of a respondent's own labor market vulnerability on his or her preferences for redistribution is significant when the partner is in an average or weak labor market position (vulnerability measures of -0.5 or higher). This implies that the effect of the respondent's own situation is significant for a clear majority of respondents (about 57\%). If the partner is, however, in a pronouncedly stable and secure employment position, the respondent's own labor market vulnerability does not significantly affect his or her preferences for redistributive policies. This finding holds similarly for preferences regarding public job creation (see the right part of fig. 2), and it suggests that the household situation needs to be taken into account when analyzing insider-outsider divides.

\section{Contextualizing the household effect: Differences between men and women}

This brings us directly to the third hypothesis according to which we expect the effect of the partner's situation on preference formation to be gender asymmetrical, with women's preferences depending more strongly on their partner's employment vulnerability than men's. Due to the notorious difficulties of interpreting interaction effects (Brambor, Roberts, and Golder 2006), we present the gender-asymmetrical interaction effects graphically in figure 3. More specifically, figure 3 displays the predicted probabilities of agreeing with the statement that the government should take measures to reduce income differences (values $=4$ and 5) or that the 

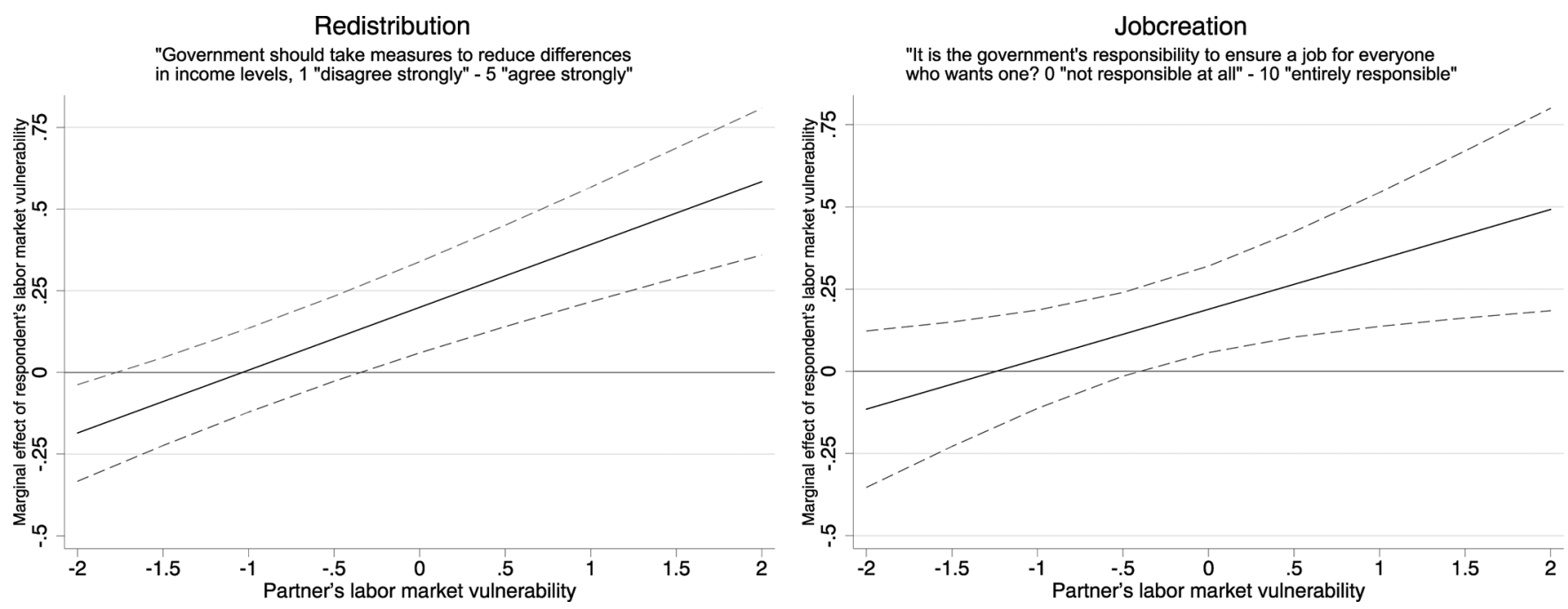

Figure 2. Marginal effect of labor market vulnerability (outsiderness) on attitudes toward redistribution and job creation, depending on the partner's labor market vulnerability. All graphs based on model specifications of model 3 in table 1 (above).

government should provide a job for everyone (values $=7$ to 10) separately for men and women. The underlying logistic regressions are shown in table D1 in the appendix. We find exactly the expected pattern: the partner's labor market vulnerability reinforces the effect of the respondent's own risk on preference formation for women significantly, but not at all for men. ${ }^{17}$

Three aspects of figure 3 are relevant: the slope of the lines, the size of the confidence intervals, and the range within which differences between men and women are significant. The lines display the average predicted probabilities for men and women separately. They show that women, whose partners also experience strong labor market risks, support redistribution very strongly (about $80 \%$ probability). Women living with an insider, on the other hand, are almost equally likely to agree or disagree with redistribution (probability of slightly more than $50 \%$ ). The strongly positive slope of the line thus suggests that women's preferences depend clearly and profoundly on the labor market situation of their partner. By contrast, the line referring to the predicted probabilities of men supporting redistribution is almost horizontal and even slightly negative, indicating that

17. When calculating the models without the interaction effect (results not shown) in order to test for direct household effects, we see that for both redistribution and job creation, the partner's labor market vulnerability has a direct and positive effect on the female respondents' preferences but it is insignificant for men. Men's preferences are mainly affected by their own labor market vulnerability. Moreover, we have calculated predicted probabilities of supporting redistribution and public job creation for singles (results not shown), and we find no gender differences. This reinforces the main point of our analysis, that is, that the household matters in people's preference formation. men's preferences depend much less on the labor market vulnerability of their partner.

The pattern of effects is almost identical for preferences regarding job creation: the probability for women to support such policies increases by about 30 percentage points if the risk of their partner changes from the minimum (insider) to the maximum (outsider) value. Again, the effect is different for men: if they live with an outsider, their support for public job creation is even lower than if they form a household with an insider. Overall, the most striking aspect of figure 3 is the opposing slopes for men and women with regard to preferences for redistribution and public job creation. The positive slopes for women indicate that their support for outsider policies is lower if they live with an insider who provides a security net, which is precisely the mechanism assumed to mitigate insider-outsider divides overall. Men, by contrast, seem to evaluate policies from a different perspective: the more precarious their partner's labor market situation, the more skeptical they are toward outsiderfriendly policies. We interpret this striking finding as reflecting a male-breadwinner logic: most men (still) have relatively secure employment (the average value of labor market vulnerability among men is around -.4 , as can be seen by the narrowest point of the confidence interval). While their own labor market risk shapes their preferences in the expected way, a precarious labor market status of their partner even seems to reinforce their insider preferences, as they disproportionately tend to carry the responsibility for the economic well-being of the household.

The second important piece of information in figure 3 concerns the number of cases: one could argue that households are very unequally distributed across the graph, so that 

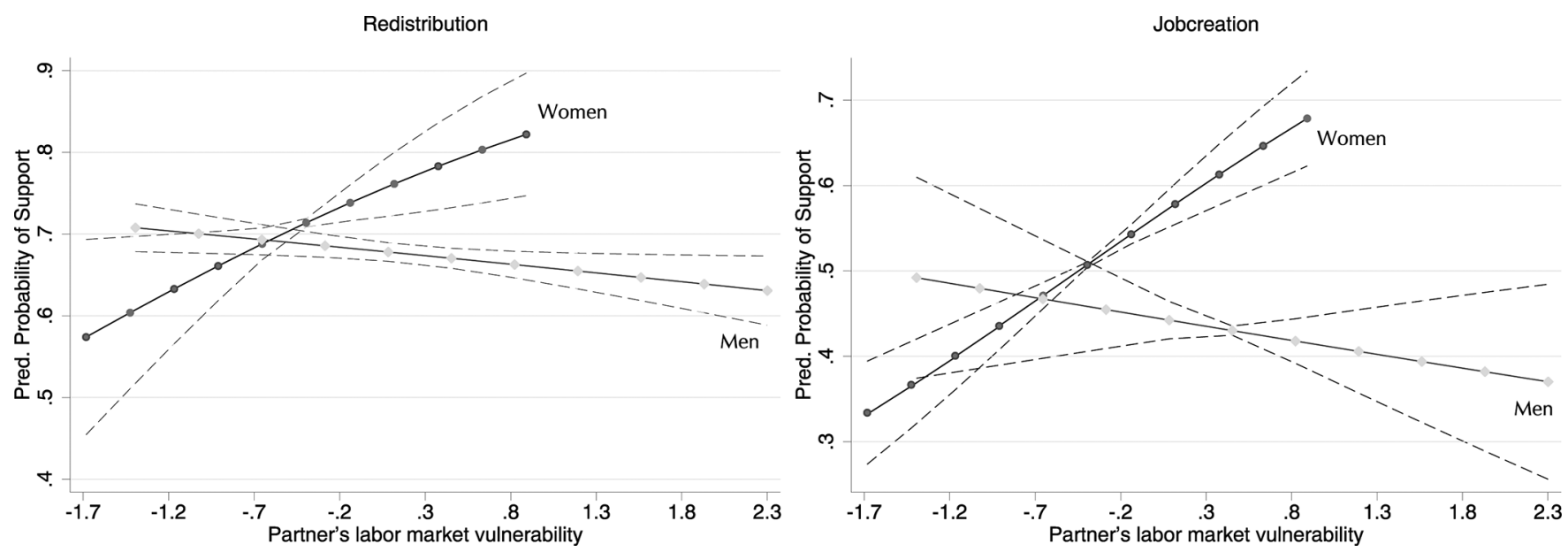

Figure 3. Predicted probability of supporting redistribution and job creation for men and women, depending on the partner's labor market vulnerability. Based on model specification as in table $\mathrm{C}_{1}$ in the appendix. Average predicted probabilities for men and women.

we risk finding strong effects that are due to very few cases. However, the size of the confidence intervals gives a precise idea of where our cases are located. Most observations are located around narrow confidence intervals (e.g., women living with partners whose labor market vulnerability is slightly negative). Fewer women live with outsider partners, which is why the confidence intervals increase in the positive range of partner's labor market vulnerability. Moreover, it is important to note that the graph only shows within-sample variations, meaning that the lines disappear when cases disappear. This explains why the lines for women end more to the left than the lines for men, as there are fewer women living with pronounced outsider partners.

The last aspect that we want to highlight in figure 3 is the range within which differences between men and women are significant, that is, the range where the confidence intervals of the two lines do not overlap. This is the case for respondents whose partner's labor market vulnerability is higher than -0.5 .

To sum up the findings of figure 3: men's preferences are largely independent from the labor market vulnerability of their partners, while women's preferences depend strongly on the labor market position of their partners.

One could argue that pooling over a diverse sample of countries might mask important differences between countries, as individual behavior and preferences are also structured by the national institutional context (Gingrich and Ansell 2012; Iversen and Rosenbluth 2006, 2010). We thus conducted separate analyses for the 13 countries in our sample. The results are shown graphically in appendix E. The gender-asymmetrical pattern we observed in figure 3 is clearly corroborated by these country-specific graphs. Opposing slopes for men and women turn out to be a very general pattern, irrespective of the domestic particularities of the welfare state in these various countries. Where the slopes are not entirely opposing, women are at least much more sensitive to a change in their partner's labor market vulnerability than vice versa.

Overall, we conclude that vulnerability in the labor market affects the social policy preferences substantially for most people. The mitigating household effect is conditional both on the labor market vulnerability of the partner and on gender, and it is relevant only for a minority of respondents. More precisely, the household neutralizes the effect of individual labor market vulnerability on social policy preferences exclusively for female outsiders living with secure partners who can provide a household safety net. In order to estimate the size of the demobilizing effect of the household, we need an operational definition of "female outsiders" and "secure partners." We make use of the natural cut-point (at the value zero) in our outsiderness measure to differentiate between women in occupational reference groups with above-average vulnerability (positive outsiderness values) and those with below-average vulnerability (negative outsiderness values). All women with positive values on the outsiderness scale are coded as female outsiders. In contrast, we define male insiders as secure partners when their vulnerability is lower than the average labor market risk among men (outsiderness values lower than -0.5). In our entire sample, almost $50 \%$ of all outsider women who do live in a household indeed have such a secure partner (i.e., a partner with labor market vulnerability below the average of male labor market vulnerability). This is an important share of outsiders and, for them, the household indeed neutralizes the effect of their own situation on preferences. 


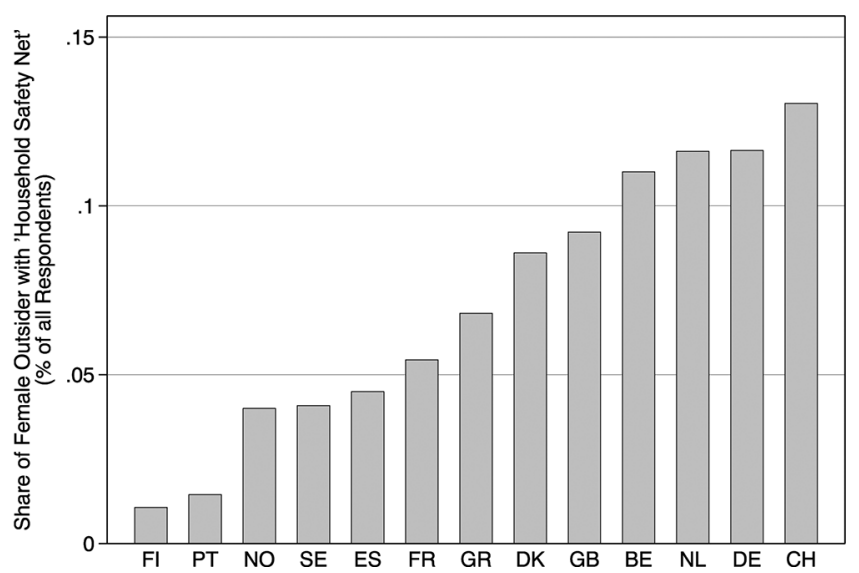

Figure 4. Share of female outsiders with safety net insider partner on total respondents, by country

However, if we discuss this result with regard to its overall relevance for the possible political mobilization of an insider-outsider divide in the entire population, we have to estimate how large a group these outsider women with secure partners is. Figure 4 shows the share of female outsiders with a safety net insider partner among all respondents for each country. In total, the (population weighted) share of female outsiders in such a situation is $8 \%$ of all respondents. The rank order of the countries by the share of outsiders with a household safety net is striking: the four countries with the largest shares of outsiders with a safety net are all Continental countries (Switzerland, Germany, the Netherlands, and Belgium), while in the Nordic (save Denmark) and Southern countries, fewer outsiders enjoy such a securing household situation. Across countries, the share of outsiders with a household safety net varies from $2 \%$ in Finland to $13 \%$ in Switzerland. That means that even in the country where the household effect affects the largest group, only the preferences of $13 \%$ of all respondents could possibly be neutralized by the household. In other words: we do find a strong effect of the household, but only for a small group of the population. ${ }^{18}$ Hence, for the large majority of respondents labor market vulnerability is clearly relevant for their social policy preferences.

\section{CONCLUSIONS}

In this article, we examined the link between labor market risks and social policy preferences. We found clear, substantial, and robust effects of labor market vulnerability on

18. This is how we arrive at a small group: in our sample, about $51 \%$ of respondents are women. About $60 \%$ of these women actually live in households. About half of those living in households are considered outsiders (i.e., labor market vulnerability above zero), and again about half of these outsider women in a household have a secure partner. preferences for different social policy principles. The higher the risk of being in unemployment or in atypical employment, the more strongly people support need-based redistribution and employment support policies. These effects are robust and they are substantial: going from the lowest to the highest value of labor market vulnerability, the predicted probability of supporting redistribution and public job creation increases by $25-30$ percentage points. Put differently: if we look at preferences for policies that actually matter for outsiders specifically (rather than general measures of welfare state generosity or employment security), we find strong effects for a large majority of respondents. This is an important precondition for a possible politicization of insider-outsider divides.

Our main finding is that labor market vulnerability correlates clearly with social policy preferences, even if we take the economic situation of the household into account. While a growing literature provides evidence for a link between labor market vulnerability and social policy preferences, no study has systematically evaluated the ways in which and the extent to which the household moderates this link. In the light of the highly unequal prevalence of labor market vulnerability among men and women, as well as the important literature on household effects in sociology, economics, andincreasingly - the voting literature, this neglect is problematic. In our article, we not only tested the moderating effect of the household situation on the link between labor market vulnerability and social policy preferences, but we also substantiated the extent and scope of this moderating effect. We demonstrate that the preference divides are not obliterated by the fact that partners forming a household tend to be exposed to different levels of labor market vulnerability. The effect of the partner's situation differs across household types and, most relevantly, for men and women. Only when the partner is a clear insider, which is the case for a minority of individuals, does an increase in the respondent's labor market vulnerability lose its effect on his or her preferences for outsider-friendly policies. Moreover, we were able to show that men's welfare state preferences are by and large independent from their partner's labor market position. Only for women do we find a clear effect of the partner's labor market vulnerability on their own preferences. Our findings are consistent with research in sociology and voting behavior, which has also shown strongly gender-asymmetric effects of the household impact. However, our study differs from these previous studies, because we look at labor market risk as the dimension of economic dependence, rather than income. Given that labor market participation is the key factor influencing women's outside options in households, we believe that our findings also speak to the voting literature, which 
might focus more strongly on labor market characteristics than in the past.

In the dualization literature, the claim that this divide runs right through the household, thereby blurring insideroutsider divides, has loomed large for a while now. Our results show that it is clearly important to take the household context into account. However, we should be careful not to throw out the baby with the bath water. Yes, households do mitigate insider-outsider divides, but only for a very limited group of the population: women who live with partners who are particularly strongly shielded from labor market vulnerability. To put this into perspective, only between $2 \%$ and $13 \%$ of respondents in each country are female outsiders with such a safety net for whom their individual position in the labor market is not relevant for preference formation.

The starting point of our analysis was the increasing inequality in the distribution of labor market vulnerability in European societies, a phenomenon becoming even more acute and salient in the context of the recent austerity crisis. Whether this inequality in labor market vulnerability translates into actual politicization of insider-outsider divides in the political arena of decision making depends on whether those affected by vulnerability think differently and want different things than those shielded from vulnerability. Since labor market vulnerability hits women more severely than men, the neutralizing effect of the household may be one reason why we have seen little of such a politicization so far, but it certainly cannot be the only explanation. Indeed, our findings suggest that the demobilizing effect takes place only in a minority of households.

However, and this is probably the most far-reaching if by now rather speculative implication of our analysis, the more vulnerability will affect men, too, the more likely such a politicization becomes, not only because men's needs have a multiplier effect on the preferences of their partners, but also because fewer and fewer women will be able to rely on a household safety net. The erosion of the male breadwinner insider status and the fact that the crisis deteriorated men's employment prospects far more than women's indeed has the potential to sharply transform welfare politics in European societies.

\section{ACKNOWLEDGMENTS}

Previous versions of this manuscript were presented at the Conference of Europeanists in 2010; at the Joint Doctoral Seminar of Oxford and Sciences Po in Paris, 2011; at the Political Economy of Skills and Inequality Workshop in Konstanz, 2012; at the ECPR joint sessions 2013; at the Harvard Kennedy School Inequality Seminar Series 2013; and at the colloquium of the University of Zurich Political Science Department, 2013. We would like to thank the participants of these seminars for their valuable comments, and in particular we would like to thank Marius Busemeyer, Torben Iversen, Fabrizio Gilardi, Peter A. Hall, Nonna Meyer, David Rueda, and Stefanie Walter for helpful feedback. We are also grateful to our anonymous reviewers and JOP editor Lanny W. Martin for their feedback and guidance.

\section{REFERENCES}

Barrows, Samuel. 2012. "Insider-Outsider Politics along New Lines: Reconsidering Dualization in Light of the Household." Unpublished manuscript, Harvard University.

Becker, Gary S. 1964. Human Capital. New York: Columbia University Press. Becker, Gary S. 1981. Treatise on the Family. Cambridge: Cambridge University Press.

Bernardi, Fabrizio, and Luis Garrido. 2008. "Is There a New Service Proletariat? Post-industrial Employment Growth and Social Inequality in Spain.” European Sociological Review 24 (3): 299-313.

Brambor, Thomas, William Roberts Clark, and Matt Golder. 2006. "Understanding Interaction Models: Improving Empirical Analyses.” Political Analysis 14:63-82.

Burgoon, Brian, and Fabian Dekker. 2010. "Flexible Employment, Economic Insecurity and Social Policy Preferences in Europe." Journal of European Social Policy 20 (2): 126-41.

Chauvel, Louis. 2009. "Comparing Welfare Regime Changes: Living Standards and the Unequal Life Chances of Different Birth Cohorts." In Ian Rees Jones, Paul Higgs, and David J. Ekerdt, eds., Consumption and Generational Change: The Rise of Consumer Lifestyles. New Brunswick: Transaction, 229-73.

Couppié, Thomas, and Michele Mansuy. 2003. "Young People and New Entrants in European Labour Markets: The Timing of Gradual Integration.” In Walter Mueller and Markus Gangl, eds., Transitions from Education to Work in Europe: The Integration of Youth into EU Labour Markets. Oxford: Oxford University Press, 63-106.

Cusack, Thomas, Torben Iversen, and Philipp Rehm. 2006. "Risks at Work: The Demand and Supply Sides of Government Redistribution." Oxford Review of Economic Policy 22 (3): 365-89.

Dancygier, Rafaela, and Stefanie Walter. 2015. "Globalization, Labour Market Risks, and Class Cleavage.” In Pablo Beramendi, Silja Häusermann, Herbert Kitschelt, and Hanspeter Kriesi, eds., The Politics of Advanced Capitalism. Cambridge: Cambridge University Press.

De Graaf, Nan Dirk, and Anthony Heath. 1992. 'Husbands' and Wives' Voting Behaviour in Britain: Class-Dependent Mutual Influence of Spouses.” Acta Sociologica 35 (4): 311-22.

De La O, Ana L.,, and Jonathan A. Rodden. 2008. "Does Religion Distract the Poor? Income and Issue Voting around the World." Comparative Political Studies 41 (4-5): 437-76.

Eichhorst, Werner, and Paul Marx. 2012. "Whatever Works: Dualization and the Service Economy in Bismarckian Welfare States.” In Patrick Emmenegger, Silja Häusermann, Bruno Palier, and Martin SeeleibKaiser, eds., The Age of Dualization: The Changing Face of Inequality in Deindustrializing Societies. Oxford: Oxford University Press, 73-99.

Emmenegger, Patrick. 2009. "Barriers to Entry: Insider/Outsider Politics and the Determinants of Job Security Regulations." Journal of European Social Policy 19 (2): 131-46.

Emmenegger, Patrick. 2010. "Gendering Insiders and Outsiders: Labour Market Status and Preferences for Job Security.” RECWOWE Working paper series 2010(2). 
Emmenegger, Patrick, Silja Häusermann, Bruno Palier, and Martin SeeleibKaiser. 2012. "How We Grow Unequal." In Patrick Emmenegger, Silja Häusermann, Bruno Palier, and Martin Seeleib-Kaiser, eds., The Age of Dualization: The Changing Face of Inequality in Deindustrializing Societies. Oxford: Oxford University Press, 3-26.

Esping-Andersen, Gosta. 1999a. "Politics without Class: Postindustrial Cleavages in Europe and America." In Herbert Kitschelt, Peter Lange, Gary Marks, and John D. Stephens, eds., Continuity and Change in Contemporary Capitalism. New York: Cambridge University Press, 293-316.

Esping-Andersen, Gosta. 1999b. The Social Foundation of Postindustrial Economies. Princeton, NJ: Princeton University Press.

Esping-Andersen, Gosta. 2000. "Who Is Harmed by Labour Market Regulations? Quantitative Evidence." In Gosta Esping-Andersen and Marino Regini, eds., Why Deregulate Labour Markets? Oxford: Oxford University Press, 66-98.

Estévez-Abe, Margarita, Torben Iversen, and David Soskice. 2001. "Social Protection and the Formation of Skills: A Reinterpretation of the Welfare State." In Peter A. Hall and David Soskice, ed., Varieties of Capitalism: The Institutional Foundations of Comparative Advantage. Oxford: Oxford University Press, 145-83.

Estévez-Abe, Margarita. 2006. "Gendering the Varieties of Capitalism: A Study of Occupational Segregation by Sex in Advanced Industrial Societies." World Politics 59 (01): 142-75.

Fernandez-Albertos, José, and Dulce Manzano. 2014. "Dualism and Support for the Welfare State?" Comparative European Politics. Electronically published August 25, 2014

Gingrich, Jane, and Ben Ansell. 2012. "Preferences in Context: Micropreferences, Macro-contexts and the Demand for Social Policy." Comparative Political Studies 45 (12): 1624-54.

Goos, Maarten, and Alan Manning. 2007. "Lousy and Lovely Jobs: The Rising Polarization of Work in Britain." Review of Economics and Statistics 89 (1): 118-33.

Hacker, Jacob S., Philipp Rehm, and Mark Schlesinger. 2013. “The Insecure American: Economic Experiences, Financial Worries, and Policy Attitudes." Perspectives on Politics 11 (1): 23-49.

Häusermann, Silja. 2010. The Politics of Welfare State Reform in Continental Europe: Modernization in Hard Times. Cambridge: Cambridge University Press.

Häusermann, Silja, Thomas Kurer, and Hanna Schwander. 2015. "HighSkilled Outsiders? Labor Market Vulnerability, Education and Welfare State Preferences?" Socio-Economic Review 13 (2): 235-58.

Häusermann, Silja, and Hanna Schwander. 2011. "Who Are the Outsiders and What Do They Want? Welfare State Preferences in Dualized Societies." Les Cahiers européens de Sciences Po no. 1

Häusermann, Silja, and Hanna Schwander. 2012. "Varieties of Dualization? Labor Market Segmentation and Insider-Outsider Divides across Regimes." In Patrick Emmenegger, Silja Häusermann, Bruno Palier, and Martin Seeleib-Kaiser, eds., The Age of Dualization: The Changing Face of Inequality in Deindustrializing Societies. Oxford: Oxford University Press, 27-51.

Inglehart, Ronald. 1977. The Silent Revolution: Changing Values and Political Styles among Western Publics. Princeton, NJ: Princeton University Press.

Iversen, Torben, and Frances Rosenbluth. 2006. "The Political Economy of Gender: Explaining Cross-National Variation in the Gender Division of Labor and the Gender Voting Gap." American Journal of Political Science 50 (1): 1-19.

Iversen, Torben, and Frances Rosenbluth. 2010. Women, Work and Politics. New Haven, CT: Yale University Press.

Iversen, Torben, and David Soskice. 2001. "An Asset Theory of Social Policy Preferences." American Political Science Review 95 (4): 875-93.
Jaeger, Mads Meier. 2006. "Welfare Regimes and Attitudes towards Redistribution: The Regime Hypothesis Revisited." European Sociological Review 22 (2): 157-70.

Jaeger, Mads Meier. 2009. "United but Divided: Welfare Regimes and the Level and Variance in Public Support for Redistribution." European Sociological Review 25 (6): 723-37.

Jessoula, Matteo, Paolo R. Graziano, and Ilaria Madama. 2010. "Selective Flexicurity in Segmented Labour Markets: The Case of Italian MidSiders." Journal of Social Policy 39 (04): 561-83.

Johnston, Ron, Kelvyn Jones, Carol Propper, Rebecca Sarker, Simon Burgessm, and Anne Bolster. 2005. "A Missing Level in the Analyses of British Voting Behaviour: The Household.” Electoral Studies 24 (2): 20125.

Kan, Man-Yee. 2014. "Household Production and the Labour Market." In G. Razzu, ed., Gender and the Labour Market in the UK. Oxford: Oxford University Press

Kan, Man-Yee, and Antony Health. 2006. "The Political Values and Choices of Husbands and Wives." Journal of Marriage and the Family 68 (1): 70-86.

Kitschelt, Herbert, and Philipp Rehm. 2006. "New Social Risk and Political Preferences." In Klaus Armingeon and Giuliano Bonoli, eds., The Politics of Post-industrial Welfare States: Adapting Post-war Social Policies to New Social Risks. London: Routledge.

Kroos, Daniela, and Karin Gottschall. 2012. "Dualization and Gender in Social Services: The Role of the State in Germany and France." In Patrick Emmenegger, Silja Häusermann, Bruno Palier, and Martin SeeleibKaiser, eds., The Age of Dualization: The Changing Face of Inequality in Deindustrializing Societies. Oxford: Oxford University Press, 100-123.

Kulin, Joakim, and Stefan Svallfors. 2013. "Class, Values, and Attitudes towards Redistribution: A European Comparison." European Sociological Review 29 (2): 155-67.

Lister, Ruth. 2004. “The Third Way's Social Investement State." In Jane Lewis and Rebecca Surender, eds., Welfare State Change: Towards a Third Way? Oxford: Oxford University Press, 157-81.

Manza, Jeff, and Clem Brooks. 2007. Why Welfare States Persist. The Importance of Public Opinion in Democracies. Chicago: Chicago University Press.

Margalit, Yotam M. 2013. "Explaining Social Policy Preferences: Evidence from the Great Recession.” American Political Science Review 107 (1): 80-103.

Marx, Paul. 2014. "Labour Market Risks and Political Preferences: The Case of Temporary Employment." European Journal of Political Research 53 (1): 136-59.

Marx, Paul, and Georg Picot. 2013. "The Party Preferences of Atypical Workers in Germany." Journal of European Social Policy 23 (2): 164-78.

Morel, Nathalie, Bruno Palier, and Joakim Palme. 2011. Towards a Social Investment Welfare State? Ideas, Policies and Challenges. Cambridge: Policy Press.

Mughan, Anthony. 2009. "Economic Insecurity and Welfare Preferences: A Micro-Level Analysis." Comparative Politics 39 (3): 293-310.

Neugart, Michael. 2008. "The Choice of Insurance in the Labor Market." Public Choice 134:445-62.

OECD (Organization of Economic Cooperation and Development). 2010. Employment Outlook 2010. Paris: OECD.

Oesch, Daniel. 2006. Redrawing the Class Map: Stratification and Institutions in Britain, Germany, Sweden and Switzerland. Basingstoke: Palgrave Macmillan.

Oesch, Daniel. 2013. Occupational Change in Europe: How Technology and Education Transform the Job Structure. Oxford: Oxford University Press.

Oesch, Daniel, and Jorge Rodriguez Menes. 2011. "Upgrading or Polarization? Occupational Change in Britain, Germany, Spain and Switzerland, 1990-2008." Socio-economic Review 9 (3): 503-31. 
Orloff, Ann Shola. 1996. "Gender in the Welfare State." Annual Review of Sociology 22:51-78.

Palier, Bruno. 2006. "Refounding Social Protection: European Experiences." Esprit (5): 53-78.

Palier, Bruno, and Kathleen A. Thelen. 2010. "Institutionalizing Dualism: Complementaries and Change in France and Germany." Politics and Societies 38 (1): 119-48.

Pierson, Paul. 2001. "Coping with Permanent Austerity: Welfare State Restructuring in Affluent Democracies." In Paul Pierson, ed., The New Politics of the Welfare State. Oxford: Oxford University Press.

Pollak, Robert A. 2003. "Gary Becker's Contributions to Family and Household Economics." Review of Economics of the Household 1 (1): 111-41.

Ranci, Constanzo. 2010. Social Vulnerability in Europe: The New Configuration of Social Risks. Basingstoke: Palgrave Macmillan.

Reeskens, Tim, and Wim van Oorschot. 2013. "Equity, Equality, or Need? A Study of Popular Preferences for Welfare Redistribution Principles across 24 European Countries." Journal of European Public Policy 20 (8): 1174-95.

Rehm, Philipp. 2009. "Risk and Redistribution: An Individual-Level Analysis." Comparative Political Studies 42 (7): 855-81.

Rehm, Philipp. 2011a. "Risk Inequality and the Polarized American Electorate." British Journal of Political Science 41 (2): 363-87.

Rehm, Philipp. 2011b. "Social Policy by Popular Demands." World Politics 63 (2): 271-99.

Rehm, Philipp, Jacob S. Hacker, and Mark Schlesinger, 2012. "Insecure Alliances: Risk, Inequality, and Support for the Welfare State." American Political Science Review 106 (2): 386-406.

Rueda, David. 2005. "Insider-Outsider Politics in Industrialized Democracies: The Challenge to Social Democratic Parties." American Political Science Review 99 (1): 61-74.

Rueda, David. 2007. Social Democracy inside Out. Partisanship and Labor Market Policy in Industrialized Democracies. Oxford: Oxford University Press.
Scheve, Kenneth, and David Stasavage. 2006. "Religion and Preferences for Social Insurance." Quarterly Journal of Political Science 1 (3): 255-86.

Schwander, Hanna, and Silja Häusermann. 2013. "Who's in and Who's Out? A Risk-Based Conceptualisation of Insiders and Outsiders." Journal of European Social Policy 23 (3): 248-69.

Sorensen, Annemette. 1994. "Women, Family and Class." Annual Review of Sociology 20:27-45.

Stegmüller, Daniel. 2013. "How Many Countries for Multilevel Modeling? A Comparison of Frequentist and Bayesian Approaches." American Journal of Political Science 57 (3): 748-61.

Strom, Marte. 2014. "How Husbands and Wives Vote." Electoral Studies 35:215-29

Taylor-Gooby, Peter. 1991. "Welfare State Regimes and Welfare Citizenship." Journal of European Social Policy 1 (2): 93-105.

Tomlinson, Mark, and Robert Walker. 2012. "Labour Market Disadvantage and the Experience of Recurrent Poverty." In Patrick Emmenegger, Silja Häusermann, Bruno Palier, and Martin Seeleib-Kaiser, eds., The Age of Dualization: The Changing Face of Inequality in Deindustrializing Societies. Oxford: Oxford University Press, 52-72.

Walter, Stefanie. 2010. "Globalization and the Welfare State: Testing the Microfoundations of the Compensation Hypothesis." International Studies Quarterly 54 (2): 403-26.

Walter, Stefanie. 2015. "Globalization and the Demand Side of Politics: How Globalization Shapes Individual Labor Market Risk Perceptions and Policy Preferences." Political Science Research and Methods. Electronically published December 1, 2015. doi:10.1017/psrm.2015.64.

Wren, Anne 2013. The Political Economy of the Service Transition. Oxford: Oxford University Press.

Zuckerman, Alan S., Jennifer Fitzgerald, and Josip Dasovic. 2005. "Do Couples Support the Same Political Parties? Sometimes: Evidence from British and German Household Panel Studies" In Alan S. Zuckerman, ed., The Social Logic of Politics: Personal Networks as Contexts for Political Behavior. Philadelphia: Temple University Press, 75-94. 